\title{
抗菌剂とポバールの表面処理による レーヨンの生分解の抑制
}

\author{
新田見 匡 1 - 村田 良太 ${ }^{2} \cdot$ 中村 健二 ${ }^{3}$ ・松本 幹治 4 ・ 中村 一穂 5 \\ 1 横浜国立大学大学院特別研究教員 工学研究院（†240-8501 神奈川県横浜市保土ヶ谷区常盤台79-5） \\ E-mail: nittami@ynu.ac.jp \\ 2 横浜国立大学大学院 工学府（†240-8501 神奈川県横浜市保土ヶ谷区常盤台79-5） \\ E-mail: d08ga646@ynu.ac.jp \\ 3正会員 清水建設株式会社 技術研究所（干135-8530 東京都江東区越中島三丁目4-17） \\ E-mail: kenji-nakamura@shimz.co.jp \\ 4横浜国立大学大学院教授 工学研究院（†240-8501 神奈川県横浜市保土ヶ谷区常盤台79-5) \\ E-mail: k-mtmt@ynu.ac.jp \\ 5 横浜国立大学大学院准教授 工学研究院（干240-8501 神奈川県横浜市保土ケ谷区常盤台79-5) \\ E-mail: naka-1@ynu.ac.jp
}

\begin{abstract}
生分解性高分子材料であるレーヨンの表面に，抗菌処理剤DC5700とポバール（PVA）をコーティング して，環境中におけるレーヨンの生分解を抑制する研究を行った。活性污泥中，バーク堆肥中において， DC5700のコーティングの有無によるレーヨンの分解期間を比較したところ, 含水率が56 wt $\%$ 以下の条件 ではコーティングをしたレーヨンの分解期間が顕著に長くなることを確認した．また含水率が40 wt $\%$ 以下 の条件では，DC5700に加えてPVAをコーティングすることで，分解期間がさらに長くなることが分かっ た. 分解に供したレーヨンに残存するDC5700を染色した結果, 低含水率の環境においては, PVAによる コーティングがレーヨンからのDC5700の剥離を抑制し，レーヨンの分解を遅らせる効果のあることが示 唆された.
\end{abstract}

Key Words : antimicrobial agent, biodegradable polymer, coating, poval, rayon, tensile strength

\section{1. 目的}

建設事業におけるプラスチック資材の用途は，土囊 や防草シート 2)，法面を保護する法枠3の袋素材など多岐 にわたる，従来これらプラスチック資材には，ポリエチ レン繊維が汎用されてきた。 しかしポリエチレン繊維は 生分解性に乏しいため, 使用後も建設現場の土壌環境中 に長期間残存寸ることとなり，生態系や景観への悪影響 が懸念されている．そのため近年では麻やポリ乳酸 （PLA）など，生分解性を有する繊維の活用が増えてき た.

生分解性材料を使用する上での重要な課題は, 生分解 性の制御である4). 上記のPLAはその生分解速度が非常 に遅く5,6)，また分解に寄与する微生物も限定されるれこ とから，使用場所によっては，ほとんど分解しないとい った問題も多く報告されている8)11). そのためPLAにポ リを-カプロラクトン（PCL）やデンプンを混合し，そ の混合比によって土壌中における分解速度（引張り強度
の低下速度）を変化させた報告がなされているす,12)，し かし複数の材料を混合寸る方法は, 分解の初期から材料 の引張り強度を低下させてしまう問題がある ${ }^{12}$. 材料の 機能を保持するうえで, 初期の引張り強度を維持するこ とは重要である.

初期の引張り強度を低下させずに分解を抑制する方法 として, 分解の速い生分解高分子材料の表面に抗菌物質 をコーティングする方法がある ${ }^{4,13)}$. 表面にシニグリン をコーティングしたPCLフィルムのコンポスト中におけ る分解実験では, 初期の引張り強度が約3週間ほど保持 されたことが報告されている ${ }^{13)}$.

PCLと同様，前記の麻は生分解速度の速い高分子材料 である，そのため建設現場において，形態の保持が求め られる期間より前に分解が進んでしまうことも多い，そ こで著者らは麻の表面にシニグリンよりも安価な抗菌処 理剂DC5700 と表面を均質化するポバール（PVA）をコ ーティングすることで，麻の生分解時間を調整すること ができないかと考えた，法面を保護する建設工事におい 
て，DC5700とPVAでコーティングした麻素材の法枠袋 を適用したところ，設置後約3年でも，袋の一部しか分 解されないという結果が得られた ${ }^{14)}$.

上記の法枠袋が分解を抑制された結果を踏まえ，本研 究ではDC5700およびPVAによるコーティングについて, 分解抑制効果のある環境，分解を抑制する期間，コーテ イング剤の適用濃度，分解抑制機構，等を調べることを 目的とした．なお本研究ではコーティングを施す素材に レーヨンを用い，活性污泥中，バーク堆肥中における分 解実験を行った．素材にレーヨンを用いた理由は，麻と 同じセルロース系繊維でありながら，生分解速度が麻に 比べて速いので，短い試験期間で現場の麻袋の分解制御 に反映可能な知見を得や寸いと考えたためである. また 引張り強度の測定において，サンプル間の誤差が少なか ったことも理由であった。

\section{2. 方法}

(1) レーヨンサンプル

実験に使用したレーヨンの原布はビスコースレーヨン (ダイワボウレーヨン製 レーヨンステープル “コロ ナ”）であった．原布レーヨンを以下1) 3)の各溶液に 浸漬して $80 \sim 120^{\circ} \mathrm{C}$ で乾燥し, 計9種類のサンプルを作成 した. 1)濃度1,3,5\% (wt/vol) の抗菌処理剤DC5700（東レ・ ダウコーニング製 Dow Coming 5700 Antimicrobial Agent (主成分3-(トリメトキシシリル)-プロピルオクタデシル ジメチルアンモニウムクロライド）溶液，2)濃度1,3,5\% (wtrol)のポバール（クラレ製 PVA-117）溶液，3)濃度 1,3,5\%のポバール(wt/vol) と濃度3\% (wt/vol) のDC5700の混 合溶液. 各レーヨンサンプルは $10 \mathrm{~mm} \times 80 \mathrm{~mm}$ カイイス に切断して分解実験に供した. 切断した各レーヨンサン プルは，1枚ずつ重量を測定し，その平均值と標準偏差 を求めた。 なおDC5700は，米国環境保護局（EPA）の認 可を取得して, 肌着などの抗菌処理に使用されている既 存の薬剤である ${ }^{15)}$.

\section{（2）活性污泥中でのレーヨン分解実験}

各種レーヨンサンプルをステンレス製のメッシュのボ ール（直径 $11 \mathrm{~mm}$, メッシュ $2 \mathrm{~mm}$ ) に入れ, 有効容積 35 Lの活性污泥槽の中に設置し, 分解実験を行った. 活性 污泥は室温, $\mathrm{pH}$ 未調整, 曝気 $2 \mathrm{~L} / \mathrm{min} の$ 条件下, グルコ 一ス $14.28 \mathrm{~g}$ ，ペプトン $7.14 \mathrm{~g}$, リン酸二水素カリウム 0.66 gを週に2回添加することにより培養した. 各種レーヨン サンプルは，週に1-2回の頻度で3枚ずつ取り出し，(4)節 に示寸方法で引張り強度と重量を測定し, その平均值と 標準偏差を求めた。

\section{（3）バーク堆肥中でのレーヨン分解実験}

ポリプロピレン製のケース $(110 \mathrm{~mm} \times 340 \mathrm{~mm} \times 260$ $\mathrm{mm}$ ）にバーク堆肥エコグリーンソイル（自然応用科 学) を約 $80 \mathrm{~mm}$ 深さとなるように入れ, 各種レーヨン サンプルを深さ $40 \mathrm{~mm}$ 程度の位置に埋めて分解実験を行 った．各ケースは $30^{\circ} \mathrm{C}$ 恒温槽内に設置した．またケー スを含めたバーク堆肥の重量を1週間ごとに測定し，重 量の減少分を霧吹きで添加することにより，含水率を20, 30, 40, 56 wt\%に保った. 各種レーヨンサンプルは2週間ご とに3枚ずつ採取し，(4), (5)節に示す方法で引張り強度, 重量, 抗菌処理剤の残存具合を調べた. なお引張り強度 と重量については, その平均値と標準偏差を求めた.

\section{（4）重量測定と引張り強度試験}

活性污泥中，バーク堆肥中で分解した各種レーヨンサ ンプルは，重量を測定した後，引張り試験機R-840（才 リエンテック）によりその引張り強度を測定した．測定 手順は，まずサンプルを $1 \mathrm{~mm}$ のッシュのふるい上で 荒く水洗いし，ビーカー内で2分間の超音波洗浄を行っ た. 次にサンプルの水分を十分に拭き取り, 温度 $23 \pm$ $2^{\circ} \mathrm{C}$, 相対湿度 $50 \pm 5 \%$ で48時間以上乾燥させ，サンプル の重量を電子天科で測定した. 最後にサンプルの両端15 $\mathrm{mm}$ を引張り試験機の引張り部位に取り付け, 下端を20 $\mathrm{mm} / \mathrm{min}$ の速度で引っ張ることにより, サンプルの引張 り強度を求めた。

\section{(5) 抗菌処理剂の染色}

抗菌処理剂DC5700を施したサンプルの一部について は, 分解実験の途中でDC5700がレーヨン表面に残存し ているかを把握するため, ブロモフェノールブルー （BPB）による染色試験间を行った。まず0.04\% (wt/vol) BPB水溶液と $10 \%(w t / v o l)$ 炭酸ナトリウム水溶液を9:1の体 積比で混合し, 試験溶液を作成した. 次にレーヨン試料 を試験溶液に入れて10秒間振とうした。試料を取り出し て水道水で濯いだ後, レーヨンの呈色とBPBの標準色 （青色）とを比較した.

\section{3. 結果と考察}

\section{（1）活性污泥中での分解実験におけるレーヨンの表面 処理の効果}

自然環境下におけるプラスチック材料の生分解性の尺 度を得る方法として，JSでは活性污泥中においてプラ スチック材料の好気的生分解度を求める方法が規定され ている17. そこで本研究においても，表面処理を施した 各種レーヨンの生分解性を評価するため, まず活性污泥 を用いたレーヨンの好気的分解実験を行った. 
レーヨンの原布と原布を $1,3,5 \%$ DC5700で処理した サンプルを活性污泥中で分解した結果を図-1に示寸．図 の重量残存率および引張り強度維持率は, 各サンプルの 初期の重量, 引張り強度に対寸る, 分解後のサンプルの 重量, 引張り強度の割合を示寸 (重量, 引張り強度はい ずれも平均値）。また表-1には重量残存率および引張り 強度維持率の標準偏差を示寸．図-1より，原布はDC5700 で処理したサンプルに比べ, その重量と引張り強度の減 少が速かった. 特に引張り強度において, 原布の引張り 強度が初期の20\%まで減少する期間は，DC5700で処理し た他のサンプルよりも9日以上短かった. 従ってDC5700 による表面処理は，レーヨンの生分解を抑制する効果が あると分かった．ただしDC5700の濃度を1,3,5\%と変え て表面処理を施したサンプルを比較すると，その分解速 度の違いは僅かであり，表-1に示寸各サンプルの標準偏 差よりも小さいものがほとんどであった.

次にレーヨンの原布と原布を1,3,5\%のPVAで処理した サンプルを活性污泥中で分解した結果を図-2（平均值）

と表-1（標準偏差）に示寸. 図-2より原布とPVAで処理 したサンプルは，重量と引張り強度における減少速度の 差は僅かであった．またその差は各サンプルの標準偏差 程度の小さいものがほとんどであった.

最後に原布を3\%のDC5700で処理したサンプル，およ び1,3,5\%のPVAと3\%のDC5700で処理したサンプルを活性 污泥中で分解する実験を行った（図-3：平均值，表-1 :
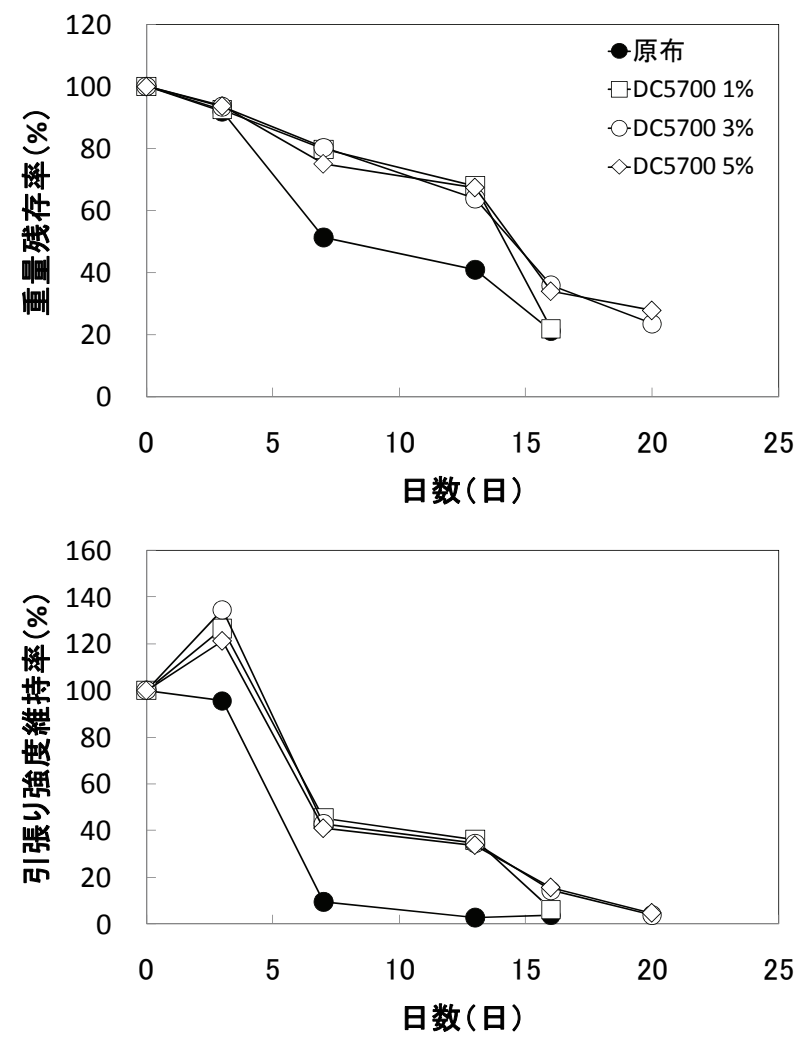

図-1 抗菌処理剂（DC-5700）で処理したレーヨンの活性污泥 中における分解
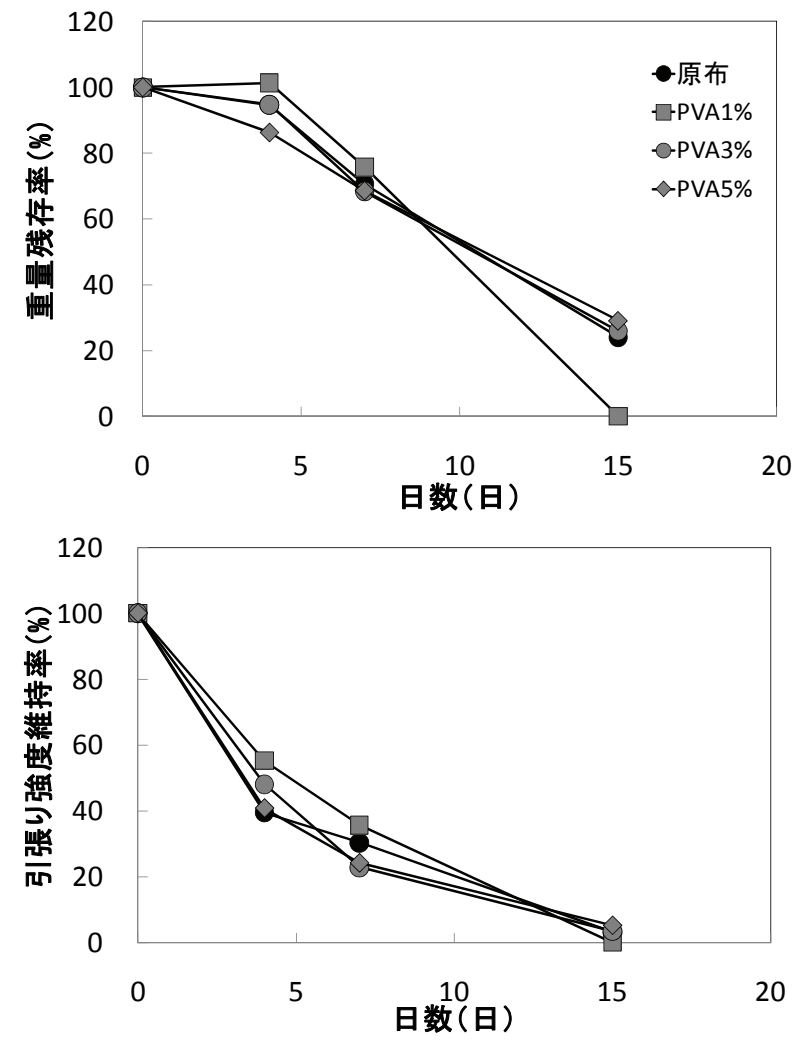

図-2 ポバール (PVA) で処理したレーヨンの活性污泥中にお ける分解
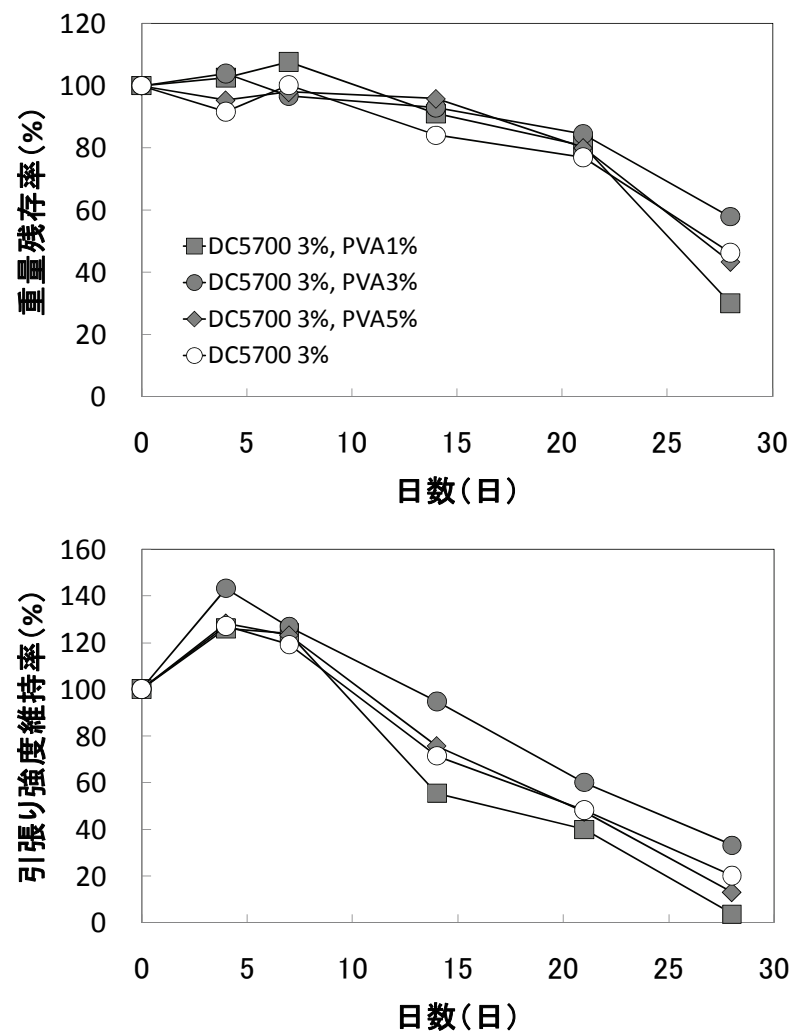

図-3 抗菌処理剤(DC-5700) とポバール（PVA）で処理したレ ーヨンの活性污泥中における分解 
表-1 図-1〜図-3に示寸各プロットの標準偏差

\begin{tabular}{|c|c|c|c|c|}
\hline \multirow[b]{2}{*}{ 日数 } & \multirow{2}{*}{ 原布 } & \multicolumn{3}{|c|}{ DC5700コーティング } \\
\hline & & 1\%(wt/vol) & $3 \%($ wt/vol) & 5\%(wt/vol) \\
\hline \multicolumn{5}{|c|}{ 図-1 重量残存率（\%） } \\
\hline 0 & 2.80 & 4.32 & 5.31 & 4.73 \\
\hline 3 & 2.24 & 3.26 & 3.11 & 5.80 \\
\hline 7 & 5.52 & 3.96 & 3.27 & 2.19 \\
\hline 13 & 4.31 & 2.14 & 1.89 & 5.74 \\
\hline 16 & 9.71 & 9.58 & 10.5 & 10.4 \\
\hline 20 & - & - & - & 9.33 \\
\hline \multicolumn{5}{|c|}{ 図-1引張り強度維持率（\%） } \\
\hline 0 & 3.65 & 5.35 & 4.75 & 15.6 \\
\hline 3 & 7.84 & 10.7 & 12.1 & 25.0 \\
\hline 7 & 3.74 & 6.15 & 9.23 & 5.00 \\
\hline 13 & 1.20 & 1.76 & 7.44 & 7.35 \\
\hline 20 & - & - & 5.59 & 4.11 \\
\hline & \multirow{2}{*}{ 原布 } & \multicolumn{3}{|c|}{ PVAコーティング } \\
\hline 日数 & & 1\%(wt/vol) & 3\%(wt/vol) & 5\%(wt/vol) \\
\hline \multicolumn{5}{|c|}{ 図-2 重量残存率 (\%) } \\
\hline 0 & 6.21 & 5.53 & 5.31 & 4.29 \\
\hline 4 & 4.45 & 0.725 & 4.49 & 0.729 \\
\hline 7 & 5.72 & 3.16 & 3.74 & 5.26 \\
\hline 15 & 3.35 & - & 5.65 & 3.57 \\
\hline \multicolumn{5}{|c|}{ 図-2引張り強度維持率（\%） } \\
\hline 0 & 5.83 & 12.7 & 5.34 & 5.63 \\
\hline 4 & 1.27 & 4.80 & 4.50 & 0.926 \\
\hline 7 & 2.93 & 5.54 & 3.29 & 5.63 \\
\hline 15 & 2.41 & - & 1.39 & 1.96 \\
\hline & \multicolumn{4}{|c|}{ DC57003\%(wt/vol)コーティング } \\
\hline 日数 & PVAなし & $\begin{array}{c}\text { +PVA1\% } \\
\text { (ut/vol) }\end{array}$ & $\begin{array}{c}\text { +PVA3\% } \\
\text { (wtlvol) }\end{array}$ & $\begin{array}{c}\text { +PVA5\% } \\
\text { (wt/vol) }\end{array}$ \\
\hline \multicolumn{5}{|c|}{ 図-3＼cjkstart重量残存率（\%） } \\
\hline 0 & - & 3.63 & 5.83 & 6.00 \\
\hline 4 & 4.55 & 4.72 & 6.71 & 6.04 \\
\hline 7 & 2.16 & 4.85 & 1.94 & 2.66 \\
\hline 14 & 4.09 & 2.05 & 3.66 & 5.85 \\
\hline 21 & 4.09 & 2.33 & 1.94 & 7.26 \\
\hline 28 & 8.05 & 3.38 & 6.25 & 1.28 \\
\hline \multicolumn{5}{|c|}{ 図-3引張り強度維持率（\%） } \\
\hline 0 & 3.53 & 5.56 & 9.27 & 1.18 \\
\hline 4 & 8.21 & 16.5 & 8.20 & 2.04 \\
\hline 7 & 6.11 & 12.2 & 9.46 & 1.80 \\
\hline 14 & 11.1 & 2.10 & 5.83 & 9.51 \\
\hline 21 & 5.67 & 1.38 & 7.40 & 5.92 \\
\hline 28 & 8.21 & 1.59 & 6.61 & 4.24 \\
\hline
\end{tabular}

※ 1または2枚のサンプルしか測定ができなかった場合は,

標準偏差の值を示さず，“一”と表記した.

標準偏差）。図-3と表-1よりDC5700のみで処理したサン プルとPVAとDC5700で処理したサンプルにおいて，重 量と引張り強度の減少速度の差は，各サンプルの標準偏 差程度の小さいものがほとんどであった．ただし図-3の 重量残存率に着目寸ると，DC5700とPVAで処理したサ ンプルのほうが，DC5700のみで処理したサンプルより も，僅かに高い值を示寸場合が多かった。

以上の活性污泥中における分解実験より，DC5700の みによる表面処理は，DC5700の適用濃度による顕著な 差異はなかったものの，レーヨンの生分解を抑制する効 果があることを確認した。一方PVAのみによる表面処理
は，PVAの適用濃度によらずレーヨンの生分解抑制効果 の低いことが分かった。またDC5700とPVAによる処理 は，DC5700のみの処理に比べ，レーヨンの生分解を抑 制する効果を僅かに高める傾向があるようだった。なお 図-1と2における原布の分解期間，および図-1とるにおけ るDC5700で処理したサンプルの分解期間は，それぞれ 大きく異なっていた．特に図-1と3においてDC5700で処 理したサンプルの引張り強度を比べると, 初期の $40 \%$ ま で低下する期間には20日ほどの違いがあった．上記のと おり本実験は温度管理をしていない活性污泥槽内での分 解実験であった．従って同じ種類のサンプルであっても， 各実験を行ったときの温度の違いにより, 分解速度が異 なったものと考える.

\section{（2）バーク堆肥中（含水率56 wt\%）での分解実験にお} けるレーヨンの表面処理の効果

表面処理を施した各種レーヨンの生分解性を土壌環境 において評価することを目的として，バーク堆肥を用い たレーヨンの分解実験を行った．前記の活性污泥中での 分解実験において, PVAのみによる表面処理は, その分 解抑制効果の低いことが明らかであった。 そのためバー ク堆肥中での分解実験では，PVAのみで処理したサンプ ルは用いず，レーヨンの原布，原布を $1,3,5 \%$ DC5700 で処理したサンプル，原布を3\%のDC5700と1,3,5\%のPVA で処理したサンプル，を用いることとした.

まずレーヨン原布および原布を $1,3,5 \%$ DC5700で処 理したサンプルを含水率56 wt\%のバーク堆肥中で分解す る実験を行った. 図-4にサンプルの重量残存率と引張り 強度維持率の平均值の経時変化，表-2に標準偏差を示寸. 図-4より原布はDC5700で処理したサンプルに比べ，その 重量と引張り強度の減少が速かった. 特に引張り強度が 初期の20\%まで低下寸る期間は，DC5700で処理した他の サンプルよりも14日以上早かった。この差は活性污泥中 での分解実験と比較しても顕著であった．図-1と図-4に おいて，原布が初期の20\%程度まで分解される期間を比 較寸ると，バーク堆肥中での分解（図-4）は活性污泥中 における分解（図-1）に比へ，重量, 引張り強度ともに 2 3倍の日数を要していたことが分かる. 従ってバーク 堆肥中では活性污泥中よりも分解が遅いために, DC5700による分解抑制が顕著に表れたものと考える. なお本分解実験では, 表-2に示寸通り, DC5700で処理し た各サンプルの標準偏差が，分解期間後半において非常 に大きかった．図-4にみられる1,3,5\%のDC5700で処理し た各サンプルの分解速度の差は, この標準偏差の大きさ に起因するものではないかと考える.

次にレーヨン原布，原布を3\%のDC5700で処理したサ ンプル，および1,3,5\%のPVAと3\%のDC5700で処理したサ ンプルを含水率56 wt\%のバーク堆肥中で分解する実験を 
行った．図-5にサンプルの重量残存率と引張り強度維持 率の平均值の経時変化，表-2に標準偏差を示寸．図-5よ りDC5700のみで処理したサンプルとPVAとDC5700で処 理したサンプルは, 原布に比べその重量と引張り強度の 減少が遅かった. 原布の引張り強度が初期の $20 \%$ まで低 下寸る期間は，図-4と同様，他のサンプルよりも14日以 上早かった。一方, DC5700のみで処理したサンプルと PVAとDC5700で処理したサンプルの重量と引張り強度 の差は, 各サンプルの標準偏差程度の小さいものであっ た。本実験においては，DC5700とPVAによる処理が DC5700のみの処理よりもレーヨンの生分解を抑制する 傾向を確認することはできなかった。

以上のバーク堆肥中での2回の分解実験（図-4,5）で は，原布およびDC5700 3\%で処理したサンプルが引張り 強度を初期の20\%まで低下させた期間は，いずれも14日 と42日であった．図-4,5の実験は温度管理をした恒温槽 内で行った分解実験であったため, 室温で実施した活性 污泥中での分解実験に比べ，同じ種類のサンプルが分解 される速度に差が少なかったものと考える．また図-4, 5 からは，DC5700，およびPVAとDC5700で処理したサン プルが，いずれも14日以上の期間，初期の80\%以上の重 量と引張り強度を保っていたことが分かった．PCLの表 面をコーティング処理した既往の報告 ${ }^{13)}$ と同様，レーヨ ンの表面をコーティングした本実験においても，コーテ イングが初期の重量や引張り強度を維持する傾向を確認 した.
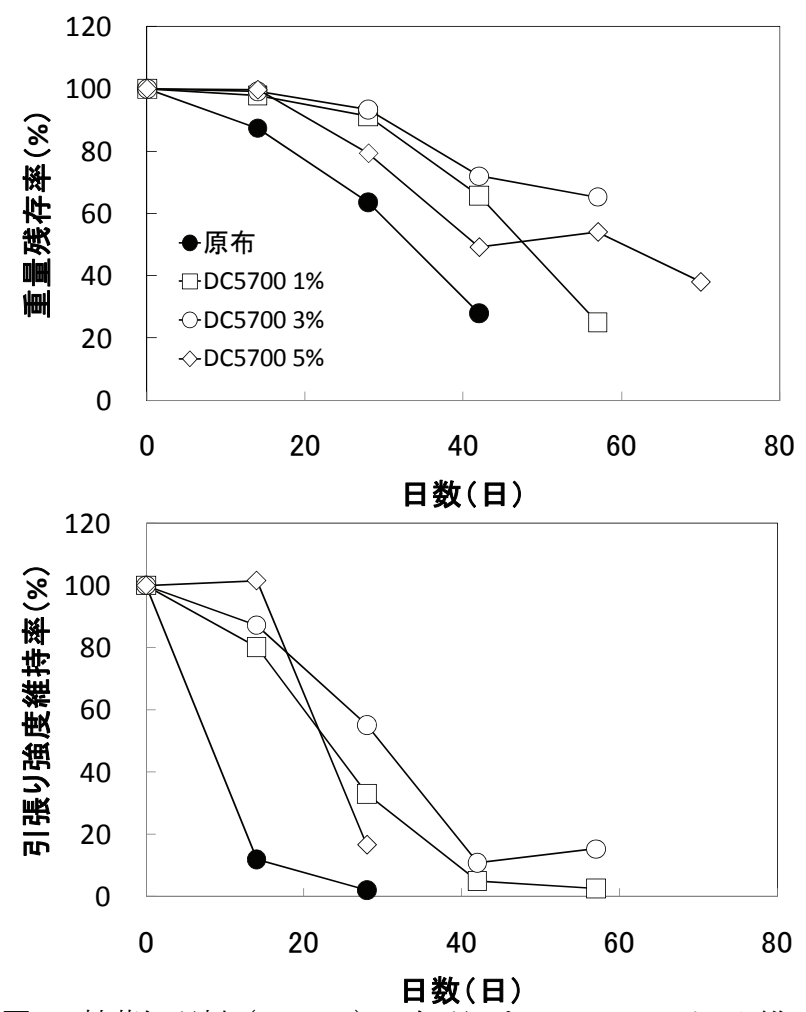

図-4 抗菌処理剂（DC-5700）で処理したレーヨンのバーク堆 肥中における分解
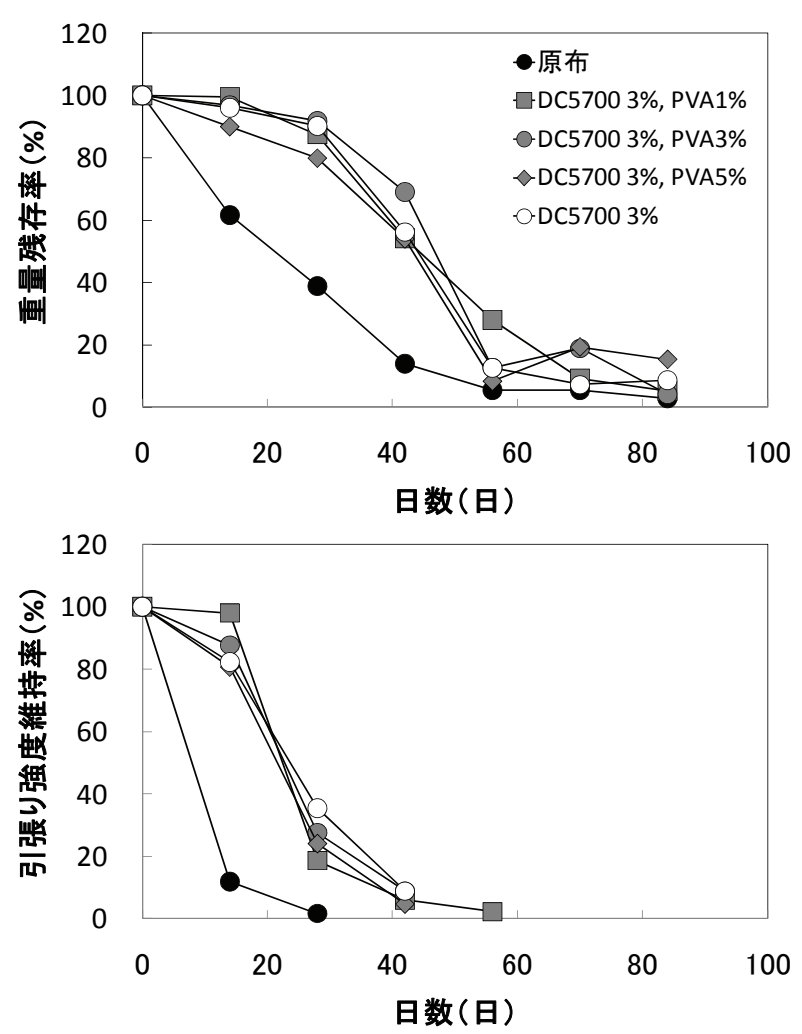

図-5 抗菌処理剤（DC-5700）とポバール（PVA）で処理した レーヨンのバーク堆肥中における分解

表-2＼cjkstart図-4,5に示す各プロットの標準偏差

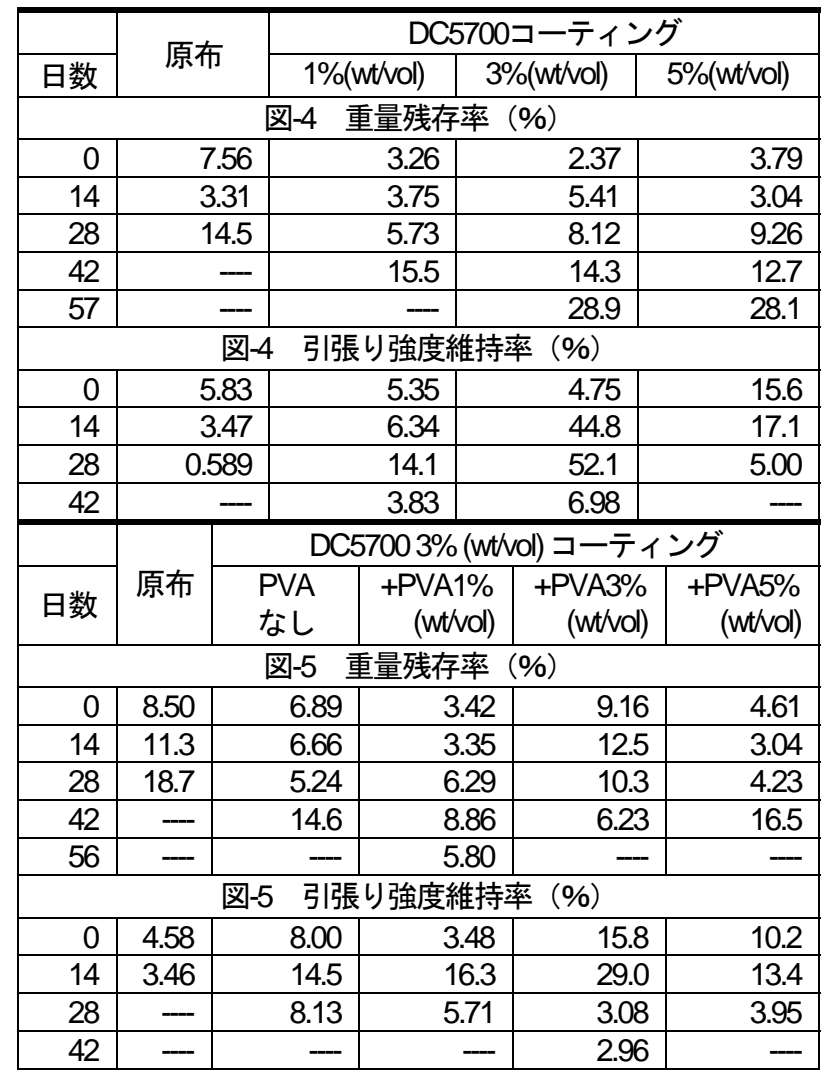

※ 1または2枚のサンプルしか測定ができなかった場合は, 標準偏差の値を示さず, “一”と表記した. 
（3）バーク堆肥中（含水率20,30,40 wt\%）での分解実験 におけるレーヨンの表面処理の効果

活性污泥中とバーク堆肥中での実験結果の比較から， 分解速度が遅い環境ほど表面処理の効果を確認しや寸い ことが分かった，既往の研究において，湿潤土䁃では乾 燥土壌に比べ，生分解性プラスチックの分解が速やかで あることが報告されていたので，分解速度をより遅く する目的で, バーク堆肥の含水率を20, 30, 40 wt\%に低下 し, 再度バーク堆肥中での分解実験を行った. ただしこ れまでの実験において，DC5700，およびPVAの濃度に よる分解抑制効果の差は顕著でなかったため, 本実験の 分解試料はレーヨンの原布を3\%のDC5700で処理したサ ンプル，および3\%のPVAと3\%のDC5700で処理したサン プルのみとした．各試料を各含水率のバーク堆肥中で分 解したときの重量残存率と引張り強度維持率の平均值の 経時変化を図-6に示寸．また表-3には重量残存率および 引張り強度維持率の標準偏差を示寸．図-6の重量変化に おいて, バーク堆肥中の含水率を30 wt\%, 40 wt\%とした 分解実験では, 42日目以降, DC5700のみで処理したサ ンプルがPVAとDC5700で処理したサンプルに対し，標 準偏差（表-3）以上の低下を示した. また引張り強度の 変化においても, バーク堆肥中の含水率を $30 \mathrm{wt} \%, 40$ wt\%とした分解実験において, 両サンプルの結果に差が 生じた.PVAとDC5700で処理したサンプルは，いずれ の含水率のバーク堆肥中においても，56日間の分解期間 を通して初期の $80 \%$ 以上引張り強度を維持した. しか LDC5700のみで処理したサンプルは，含水率を $40 \mathrm{wt} \%$ とした実験では28日，含水率を30 wt\%とした実験では42 日で引張り強度が初期の15\%以下に減少した.

以上より含水率が低く分解速度の遅い実験系において は，PVAとDC5700による処理は，DC5700のみの処理よ りも分解を抑制する効果が高いことが分かった．なお含 水率を20 wt\%とした分解実験では, DC5700のみで処理 したサンプルとPVAとDC5700で処理したサンプルとも に, 重量は初期の $90 \%$ 以上，引張り強度は初期の $80 \%$ 以 上を実験最終日（56日）において維持していた．含水率 20 wt\%のバーク堆肥中では分解速度が遅いため, 今回の 分解期間（56日）ではPVA処理の有無によらず分解が進 まなかったものと考える.

\section{（4）バーク堆肥および活性污泥の含水率と各種レーヨ ンの分解期間との関係}

レーヨンの分解を行った環境 (バーク堆肥と活性污 泥）の含水率とレーヨンの分解期間との関係を整理する ため, 図-1, 5, 6においてレーヨンの引張り強度が初期の 80\%および50\%まで低下するのに要した日数をその実験 を行った環境（バーク堆肥および活性污泥）の含水率と ともに図-7にまとめた．ただし図-6において分解が所定
の割合に達しなかったサンプルについては, 分解に要し た日数を56日として表記した. 図-7よりレーヨンの引張 り強度が初期の $80 \%$ よび50\%まで低下するいずれの場 合においても，DC5700の表面処理による効果が顕著に 表れたのは, 含水率が56 wt\%以下の環境であり, DC5700 とPVAの表面処理による効果が表れたのは，含 水率が40wt\%以下の環境であったことが分かる.

\section{（5）分解過程における抗菌処理剂のコーティング状態 とその生分解抑制との関係}

上記の結果より, 低含水率の分解環境においては,
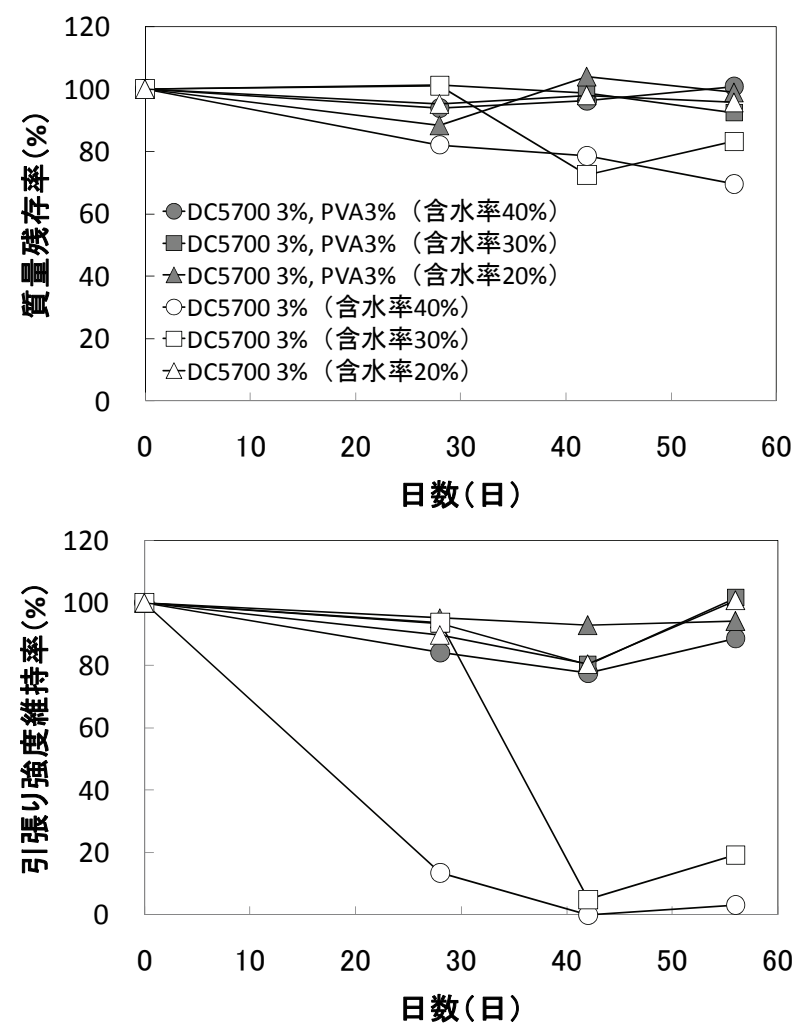

図-6 含水率を変えたバーク堆肥中におけるレーヨンの分解

表-3 図-6に示す各プロットの標準偏差

\begin{tabular}{|c|c|c|c|c|c|c|}
\hline & \multicolumn{6}{|c|}{ 含水率 (Wt\%) } \\
\hline & 40 & 30 & 20 & 40 & 30 & 20 \\
\hline \multirow{2}{*}{ 日数 } & \multicolumn{6}{|c|}{ DC5700 3\% (wt/vol) コーティング } \\
\hline & \multicolumn{3}{|c|}{ PVAなし } & \multirow{2}{*}{$\begin{array}{l}\text { +PVA } \\
\%)\end{array}$} & \multicolumn{2}{|c|}{ 3\%(wt/vol) } \\
\hline \multicolumn{6}{|c|}{ 図-6＼cjkstart重量残存率（\%） } & \\
\hline 0 & 5.72 & 5.79 & 4.22 & 5.25 & 6.43 & 8.00 \\
\hline 28 & 9.87 & 8.02 & 7.81 & 4.99 & 7.99 & 7.99 \\
\hline 42 & - & - & 2.10 & 5.25 & 4.21 & 2.44 \\
\hline 56 & 10.1 & 11.0 & 6.20 & 2.29 & 5.23 & 0.677 \\
\hline \multicolumn{7}{|c|}{ 図-6 引張り強度維持率（\%） } \\
\hline 0 & - & - & - & - & - & - \\
\hline 14 & - & 19.7 & 4.64 & 14.9 & 6.83 & 3.31 \\
\hline 28 & - & - & 11.4 & 12.5 & 4.74 & 14.5 \\
\hline 42 & - & - & 4.09 & 14.1 & 21.1 & 7.59 \\
\hline
\end{tabular}

※ 1または2枚のサンプルしか測定ができなかった場合は,

標準偏差の值を示さず, “一”と表記した. 

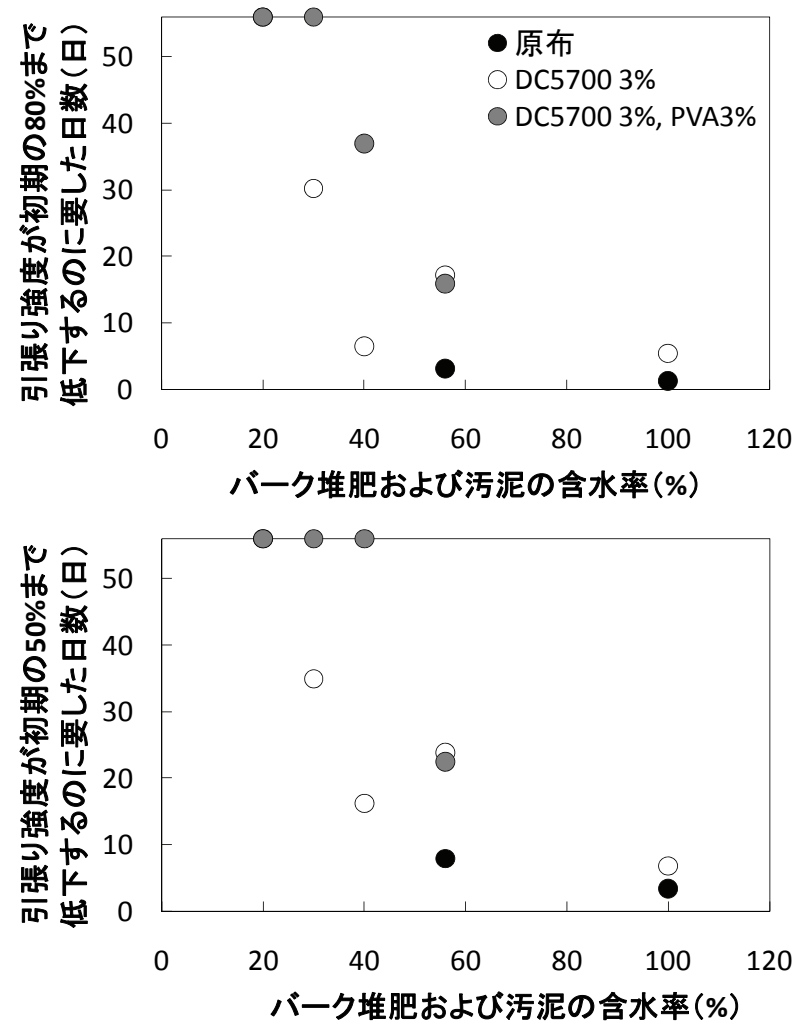

図-7 引張り強度の低下と土壌および污泥の含水率との関係

DC5700に加えてPVAをコーティングすることで，レー ヨンの分解が抑制されることが分かった．そこで低含水 率（30 wt\%）のバーク堆肥中で分解したサンプルの DC5700のコーティング状態の変化を調べるため, 分解 過程においてDC5700のみおよびDC5700とPVAでコーテ イングしたサンプルをBPBで染色した．結果を図-8に示 す. 分解0日目においては, DC5700のみで処理したサン プル，DC5700とPVAで処理したサンプルともに青く染 色されている．これは両サンプルの表面にDC5700が塗 布されている状態であったことを示寸．しかし分解42日 目以降，DC5700 のみで処理したサンプルは青く染まら なくなった．図-6に示寸とおり，DC5700のみで処理した サンプルは，28日目から42日目の間に引張り強度が激减 した．BPB染色の結果とあわせて考えると，DC5700が残 存している期間はレーヨンの分解が抑制され，DC5700 が失われた後にレーヨンの分解が進んだものと推察でき る. 一方DC5700とPVAで処理したサンプルは，図-8に示 すとおり分解56日目まで青く染色された。 これはPVA処 理によりDC5700の剥離が抑制されたことを示唆する結 果であった．また図-6よりDC5700とPVAで処理したサン プルは56日間では分解が進まなかったことから， DC5700 とPVAで処理したサンプルにおいても，DC5700 が残存している期間はレーヨンの分解が抑制されたもの と推察する.

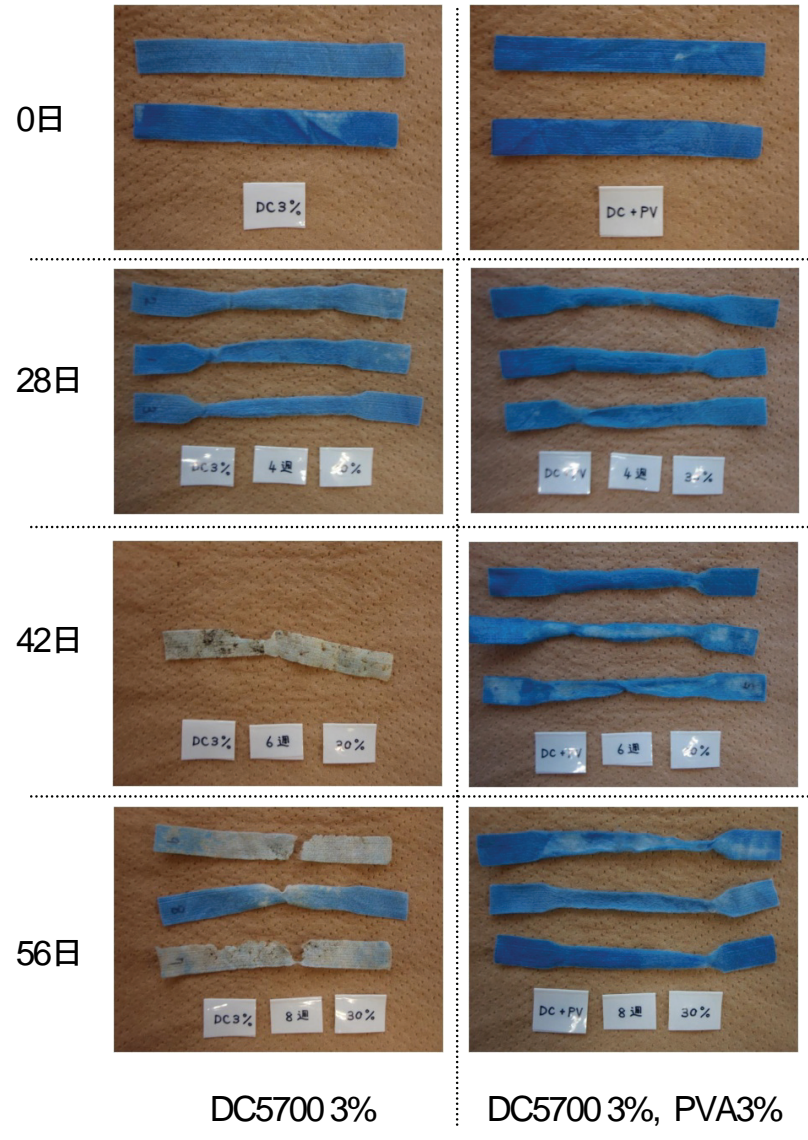

図-8 含水率30 wt\%のバーク堆肥中で分解したレーヨンのBPB による染色試験

\section{4. 結論}

本研究では, 生分解性の高い繊維であるレーヨンに, PVAおよび抗菌処理剤のDC5700をコーティングし，活 性污泥中とバーク堆肥中において，その分解抑制効果を 調べた. 本研究で得られた知見を以下にまとめる.

- DC5700の表面処理による効果が顕著に表れたのは, 含水率が56 wt\%以下の環境であった．また含水率が 40 wt\%以下の環境では，DC5700に加えPVAの表面処 理を行うことで，その分解抑制効果が大きくなった.

- 温度 $30^{\circ} \mathrm{C}$, 含水率56 wt\%のバーク堆肥中において, DC5700 のみ，およびDC5700 とPVAのコーティング を施したレーヨンは, 初期の引張り強度（初期の 80\%以上の引張り強度）を原布のレーヨンよりも2週 間程度長く保持できた。

・ 表面処理に用いるDC5700およびPVAの濃度が1-5\% (wt/vol)の範囲では，濃度差による明らかな分解抑制 効果の差を確認できなかった。

- DC5700が表面に残存している期間はレーヨンの分解 が抑制され，DC5700が表面から剥がれるとレーヨン の分解が進むことが示唆された。 また低含水率の環 境においては，PVAのコーティングがDC5700の剥離 
を防ぐ効果があったものと推測する.

\section{参考文献}

1) 中村健二：赤土流亡対策用土襄袋の生分解性に関す る研究，土木学会第 58 回年次学術講演会論文集 VII, pp. 139-140, 2003.

2) 山本孝, 木水貢, 森大介：新保善正環境調和型産業 資材の実証化 生分解性繊維の実用化, 石川県工業 試験場研究報告，No. 49，pp. 25-30，2000.

3) 中村健二，伊東優介，新田見匡，松本幹治，中村一 穂 : 尿素を用いたバーク堆肥中でのポリ乳酸(PLA)の 分解, 日本緑化工学会誌, Vol. 35, No. 1, pp. 21-26, 2009.

4) 技術情報協会 : 生分解性プラスチックの改質技術之 成形加工における課題と対策, pp.1-23，2003.

5）北川和男：生分解性プラスチックの土壤分解性につ いて，材料，Vol. 51, No. 6, pp.707-708, 2002.

6) Tsuji, H., Mizuno, A. and Ikeda, Y. : Blends of Aliphatic Polyesters. III. Biodegradation of Solution-Cast Blends from Poly (L-lactide) and Poly ( $\varepsilon$-caprolactone), J. Appl. Polym. Sci., Vol. 70, pp. 2259-2268, 1998.

7) 酒井清文, 森芳邦彦, 中山敦好, 山野尚子：自然環 境中における生分解性プラスチック分解菌の分布, 高分子学会予稿集, Vol. 52, No. 5, p. 979, 2003.

8) 黒木泰至, 鳥越清, 福地哲郎, 小玉義和：生分解性 プラスチックのフィールドテスト第 1 報，宮崎県工 業技術センター・宮崎県食品開発センター研究報告, No. 44, pp. 51-54, 2001.

9) 佐野正，林成美，天城裕子，佐藤亨：生分解性プラ スチックのフィールドテスト，新潟県工業技術総合
研究所工業技術研究報告書, No. 30, pp. 55-58, 2001.

10) 田村克浩，金子亜由美：生分解性プラスチックの土 壤分解性フィールドテスト, 静岡県静岡工業技術セ ンター研究報告, No. 47, pp. 21-25, 2002.

11) 中井猛夫, 野村賀寿雄, 三橋正典, 西村敬一：生分 解性プラスチックのフィールドテスト・暴露試験, 奈良県工業技術センター研究報告，No. 28, pp. 13-18, 2002.

12) 大澤敏, 附木貴行, 小川俊夫 : ポリ乳酸/デンプンブ レンド射出成形物の土壤中における分解制御, 高分 子論文集, Vol. 58, No. 11, pp. 573-580, 2001.

13) 大澤敏 : 天然抗菌物質を利用した生分解性プラスチ ックの分解制御, 高分子加工, Vol. 52, No. 7, pp. 16-22, 2003.

14) 中村健二：建設事業における緑化への繊維活用に関 する研究, 博士学位論文, 横浜国立大学, pp.44-45, 72-73, 2010.

15) 河合博: Dow Corning 5700 抗微生物処理剤, 人にや さしい繊維と加工, pp. 535-540, 䋊維社, 1995.

16) 河合博：抗菌防臭加工剂有機シリコン第四アンモニ ウム塩, 抗菌防臭, pp. 128-139, 繊維社, 1989.

17) 日本工業規格（JIS）：プラスチックー水系培養液中 の好気的究極生分解度の求め方一閉鎖呼吸計を用い る酸素消費量の測定による方法，JIS K 6950:2000 (ISO 14851:1999), 2000.

18）鴨田福也：園芸分野における生分解性プラスチック, バイオサイエンスとインダストリー, Vol. 58, No. 11, pp. 811-814, 2000.

(2010.6. 4 受付)

\section{DECOMPOSITION SUPPRESSION OF RAYON BY SURFACE COATING USING ANTIMICROBIAL AGENTS AND POVAL}

\section{Tadashi NITTAMI, Ryota MURATA, Kenji NAKAMURA, Kanji MATSUMOTO and Kazuho NAKAMURA}

The authors examined whether decomposition of rayon in environment is suppressed by coating it with antimicrobial agent DC5700 and poval (PVA). When the rayon samples coated with DC5700 were decomposed in activated sludge or bark compost together with non-coated samples, the coated samples needed longer time for the decomposition comparing to the non-coated samples under the environmental condition whose water content is $56 \%$ or less. Moreover, PVA coating together with DC5700 further extended the decomposition time of rayon samples under the condition whose water content is $40 \%$ or less. The dyeing test of DC5700 using bromphenol blue indicated that PVA coating together with DC5700 prevented DC5700 from removing from the rayon surface under the low-water-content condition and thus the double coating sample was decomposed slowly. 